\title{
Interaction of Treponema pallidum with isolated rabbit capillary tissues
}

\author{
E E QUIST,* L A REPESH,† R ZELEZNIKAR,* AND T J FITZGERALD \\ From the Departments of ${ }^{*}$ Pharmacology, †Biomedical Anatomy, and $\$$ Medical Microbiology and \\ Immunology, School of Medicine, University of Minnesota, Duluth, Minnesota, USA
}

SUMMARY Within infected tissue Treponema pallidum shows a characteristic predilection for perivascular areas. After intact capillaries had been prepared from rabbit brain tissue treponemes were incubated with isolated capillaries and visualised by darkfield, phase contrast, and scanning electron microscopy. The organisms rapidly attached to the surface of the capillaries at the tip of the treponeme; attached organisms retained motility for longer periods than unattached organisms. Treponema pertenue also attached to capillaries. Heat-inactivated $T$ pallidum and three non-pathogenic treponemes did not, however, attach to the capillaries. Immune rabbit serum contains a factor that blocks the attachment of $T$ pallidum to capillaries. Compared with cultured mammalian cells capillaries should provide a better tool for investigating host-parasite relationships in syphilis.

\section{Introduction}

Syphilis can be described as a generalised infection of vascular tissues. ${ }^{1}$ Within lesions in each stage of infection Treponema pallidum localises primarily in perivascular areas. Tissue culture has been useful in studying certain aspects of the pathogenesis and immunology of treponemes. ${ }^{2}$ The organisms firmly attach to cultured cells ${ }^{3}$; this attachment enhances treponemal survival ${ }^{4}$; and immune rabbit serum contains a factor(s) that blocks treponemal attachment to the cells. ${ }^{56} \mathrm{~A}$ similar type of attachment apparently occurs in vivo; motile treponemes have attached to pieces of dermal and testicular tissue. ${ }^{5}$ In addition, $T$ pertenue, the causative agent of yaws, attaches to cultured cells whereas non-pathogenic treponemes do not. ${ }^{4} 7$ These observations form the basis of the hypothesis that the ability of treponemes to attach is an important part of the disease process; as a corollary blockage of attachment may be an important part of the healing process. ${ }^{56}$

Host tissue cells that have been minced, trypsinised, grown in culture, and passaged a number of times lose many of their in-vivo characteristics. In addition, certain cells rapidly overgrow other cells

Address for reprints: Dr T J Fitzgerald, Department of Medical Microbiology, and Immunology, School of Medicine, University of Minnesota, Duluth, MN 55812, USA

Accepted for publication 18 July 1982 thereby destroying in-vivo relationships. Techniques are available for isolating capillary-enriched preparations from the brain cortex of dogs and rats. ${ }^{8-10}$ The purpose of this study was to adapt these techniques to rabbit tissues in order to provide a better system for studying host-parasite relationships in syphilis.

\section{Materials and methods}

\section{$T$ PALLIDUM}

The Nichols strain was passaged intratesticularly in Dutch Belt rabbits. The animals were maintained at $18^{\circ} \mathrm{C}$ and given antibiotic-free food and water. Each testis was inoculated with $1 \times 10^{7}$ to $3 \times 10^{7}$ treponemes. Animals were killed after 9 to 11 days and the testes removed, minced with scissors, and extracted at room temperature in Eagle's minimal essential medium supplemented with $4 \mathrm{mmol} / 1$ $\mathrm{NaHCO}_{3}, 30 \mathrm{mmol} / 1$ HEPES (n-2-hydroxyethylpiperazine- $\mathrm{N}-2$ ethanesulphonic acid), $1 \mathrm{mmol} / \mathrm{l}$ dithiothreitol, and $10 \%$ heat-inactivated rabbit serum $\left(56^{\circ} \mathrm{C}\right.$ for $3 \mathrm{C}$ minutes). After extraction for 20 to 25 minutes the preparation was centrifuged at $1000 \times g$ for 10 minutes at $24^{\circ} \mathrm{C}$ to sediment particulate matter, and the supernatant containing the organisms was removed. In most experiments this preparation was then centrifuged at $18000 \times g$ for 30 minutes at $4^{\circ} \mathrm{C}$. The supernatant was discarded and the pelleted treponemes were resuspended in fresh tissue culture medium. Treponemes were adjusted to 
$2 \times 10^{7}$ to $6 \times 10^{7}$ organisms/ml using a PetroffHausser chamber. In some experiments treponemes were heat-inactivated at $56^{\circ} \mathrm{C}$ for 10 minutes.

\section{OTHER TREPONEMES}

$T$ pertenue was provided by $\mathrm{Dr}$ Ronald Schell at Hahnemann Medical College. The organisms were grown intratesticularly in rabbits. After 20 to 30 days treponemes were harvested and processed similarly to $T$ pallidum. Treponema denticola, Treponema vincentii, and Treponema phagedenis biotype Kazan 5 were provided by Dr Russell C Johnson at the University of Minnesota. These non-pathogens were grown anaerobically at $37^{\circ} \mathrm{C}$ in medium containing $20 \%$ fetal bovine serum heated to $56^{\circ} \mathrm{C}$ for 30 minutes, $1 \%$ trypticase, $1 \%$ yeast extract, $1 \%$ glucose, and $0.08 \%$ cysteine. This medium was supplemented with $10 \mathrm{ml} /$ litre of the following salt solution: $0 \cdot 2 \% \mathrm{MgSO}_{4} \cdot 7 \mathrm{H}_{2} \mathrm{O}, 0 \cdot 13 \% \mathrm{CaCl}_{2} \cdot 2 \mathrm{H}_{2} \mathrm{O}$, $1.0 \% \mathrm{NaCl}$, and $5 \cdot 0 \%\left(\mathrm{NH}_{4}\right)_{2} \mathrm{SO}_{4}$. In addition, $10 \mathrm{ml} /$ litre of buffer $(\mathrm{pH} \mathrm{7.4)}$ containing $27 \cdot 3 \mathrm{~g}$ $\mathrm{KH}_{2} \mathrm{PO}_{4} /$ litre, $139.2 \mathrm{~g} \mathrm{~K}_{2} \mathrm{HPO}_{4} /$ litre, and $50.0 \mathrm{~g}$ $\mathrm{NaHCO}_{3} /$ litre was added.

\section{CAPILLARIES}

A procedure was adapted from previous techniques $^{8-10}$ to isolate microvessels from the rabbit brain under sterile conditions. Animals were killed by intracardiac injection of sodium pentabarbital. The skull was removed and the cerebral cortex placed in cold saline. All further procedures were performed at $4^{\circ} \mathrm{C}$. The pia was removed and the cortical grey matter suspended in 5 volumes of Ringers-Henseleit buffer $\left(\mathrm{NaCl} 6.9 \mathrm{~g} / \mathrm{l}, \mathrm{KCl} 0.5 \mathrm{~g} / \mathrm{l}, \mathrm{NaHCO}_{3} 2 \cdot 1 \mathrm{~g} / \mathrm{l}\right.$ $\mathrm{CaCl}_{2} \mathbf{0} \cdot 28 \mathrm{~g} / \mathrm{l}, \mathrm{MgCl}_{2} \cdot 7 \mathrm{H}_{2} \mathrm{O} 0 \cdot 28 \mathrm{~g} / 1, \mathrm{KH}_{2} \mathrm{PO}_{4} 0 \cdot 16$ $\mathrm{g} / \mathrm{l}$ ) and homogenised in a Tri-R Stir-R homogeniser. This preparation was centrifuged at $200 \times g$ for 10 minutes. The pellet was resuspended in 2 volumes of $20 \%$ dextran (molecular weight 60400 , Sigma) in buffer and centrifuged at $1700 \times g$ for 15 minutes. The top layer containing most of the myelin was discarded. The pellet was resuspended in buffer and layered on $13 \%$ dextran and centrifuged at $1700 \times g$ for 15 minutes to remove the remaining myelin. To remove erythrocytes and nuclei the resuspended pellet was passed through a column of glass beads $(0.25$ to $0.30 \mathrm{~mm}$ in diameter). These microvessel preparations were comprised of approximately $95 \%$ capillaries and $5 \%$ arterioles ${ }^{\circ}$ and venules. Most capillaries were from 0.5 to $1.0 \mathrm{~mm}$ in length. Preparations were usually used immediately; if necessary, however, they could be maintained at $4^{\circ} \mathrm{C}$ for five days without loss of viability.

After isolation the capillaries were centrifuged at $200 \times g$ for 10 minutes. The supernatant was discarded and the pelleted capillaries were resuspended with freshly harvested treponemes. Numbers of attached organisms were determined per $0.5 \mathrm{~mm}$ length of capillary using a stage micrometer and darkfield microscopy.

\section{SCANNING ELECTRON MICROSCOPY}

Treponemes were incubated with capillaries in test tubes or in Sykes-Moore chambers ${ }^{11}$ at $37^{\circ} \mathrm{C}$ in an atmosphere of $2 \cdot 5 \%$ oxygen $\cdot 5 \%$ carbon dioxide - $92 \cdot 5 \%$ nitrogen. Samples were rinsed three times with phosphate-buffered saline, $\mathrm{pH} 7 \cdot 6$, to remove unattached treponemes, then fixed with $3 \%$ glutaraldehyde in $0.1 \mathrm{~mol} / 1$ sodium cacodylate buffer, $\mathrm{pH} 7 \cdot 2$, at room temperature for one hour. After being rinsed three times with $0.1 \mathrm{~mol} / 1$ sodium cacodylate buffer capillaries were post-fixed in $1 \%$ $\mathrm{OsO}_{4}$ in $0.1 \mathrm{~mol} / 1$ sodium cacodylate for 30 minutes, washed three times in double distilled water, and stained in $2 \%$ aqueous uranyl acetate for 30 minutes. Capillaries were then washed twice in double distilled water and dehydrated through ascending grades of alcohol to $100 \%$. Preparations were critical-point dried with carbon dioxide, mounted on aluminum stubs with double-stick tape, and coated with goldpalladium in a Hummer II evaporator. Capillaries were examined with an AMR 1000 scanning electron microscope $(20 \mathrm{kV})$.

\section{BLOCKAGE EXPERIMENTS}

The previous protocol for blockage of treponemal attachment to tissue culture cells by immune serum was used. ${ }^{5}$ On the day of the experiments pooled sera were obtained from three immune rabbits that had been infected 16 to 20 months previously and challenged intradermally with $10^{8}$ treponemes monthly. Pooled sera were also obtained from three rabbits not previously exposed to $T$ pallidum. Sera were heated at $56^{\circ} \mathrm{C}$ for 30 minutes. Treponemal preparations were adjusted to $2 \times 10^{7}$ to $4 \times 10^{7}$ organisms $/ \mathrm{ml}$ in extraction medium. An equal volume of normal or immune serum was then added. These preparations were preincubated for 18 to 22 hours at $37^{\circ} \mathrm{C}$ in $2.5 \%$ oxygen. These treponemes were then added to capillaries. After incubation for 3.5 to 4.5 hours at $37^{\circ} \mathrm{C}$ the number of attached treponemes per $0.5 \mathrm{~mm}$ capillary was determined by darkfield microscopy.

\section{Results}

Preliminary experiments used capillaries isolated from brain tissues of dogs. The addition of $T$ pallidum to these preparations resulted in attachment of treponemes to the capillary surfaces. Since the rabbit is the experimental model that most closely mimics human infection further experiments were 
performed with capillaries isolated from rabbits. Attachment was observed with both darkfield and phase contrast microscopy. The interaction of treponemes with rabbit capillaries was similar to that previously described for tissue culture cells. ${ }^{2} 4612$ Organisms were attached immediately after inoculation. Attachment was mediated through the tip of one end of the treponeme, although occasionally organisms were attached at both ends. Treponemes were attached in random fashion along the entire length of all the capillaries present. Actively motile organisms could not be dislodged by vigorous mixing or by pressure applied to coverslip slides. With larger inocula of treponemes increasing numbers of organisms were attached.

Three other observations confirmed previous findings using tissue culture cells. ${ }^{457}$ Firstly, capillary attachment required motile organisms. Heatinactivated $T$ pallidum failed to attach firmly, indicating that the attachment process involves metabolically active organisms. Initially, some organisms attached; washing of the capillaries, however, removed all organisms. This is in contrast with viable attached treponemes which could not be removed by washing. Secondly, $T$ pertenue attached to capillaries in an identical fashion to that described for $T$ pallidum. Thirdly, non-pathogenic treponemes did not attach to capillaries. Preparations of $T$ denticola, $T$ vincentii, and $T$ phagedenis biotype Kazan 5 at $5 \times 10^{7}$ organisms/ml were incubated anaerobically with capillaries. After 24 hours the non-pathogens retained active motility; no organisms were attached to the capillary surfaces.

In further experiments scanning electron microscopy was used to provide a three-dimensional view of attached $T$ pallidum. The isolation of treponemes requires testicular extraction followed by slow-speed centrifugation to pellet tissue debris and blood cells. The supernatant contains the organisms in addition to soluble inflammatory, treponemal, and testicular material. The addition of these treponemes to capillary preparations resulted in the immediate precipitation of long strands of fibrin-like material. As shown in fig 1 these strands were readily distinguishable from the corkscrew-shaped organisms and anchored the capillaries to the glass

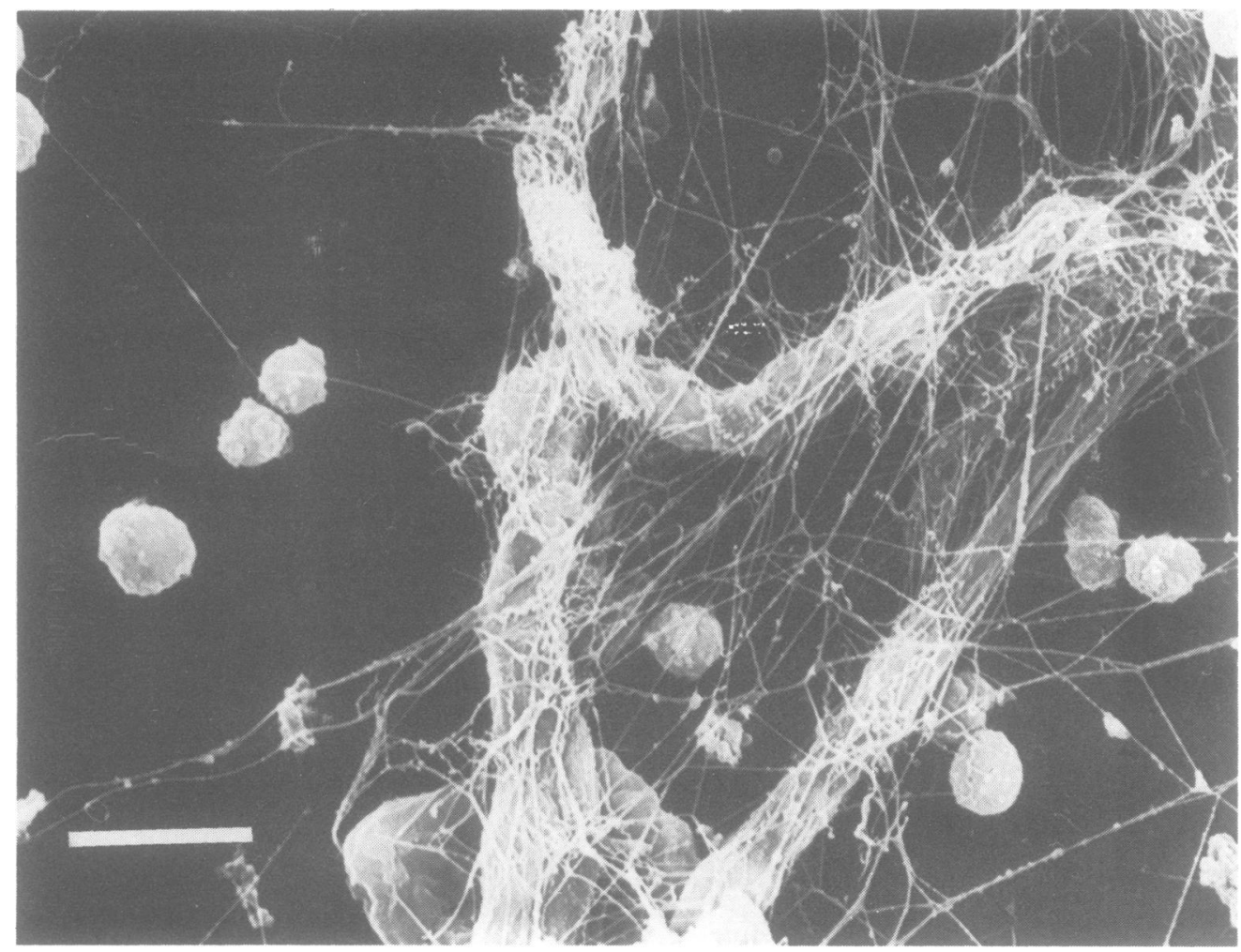

FIG 1 Scanning electron micrograph of capillaries incubated with slow-speed centrifuged treponemes. Long fibrin-like strands are readily differentiated from the coiled organisms. Bar represents $30 \mu \mathrm{m}$. 

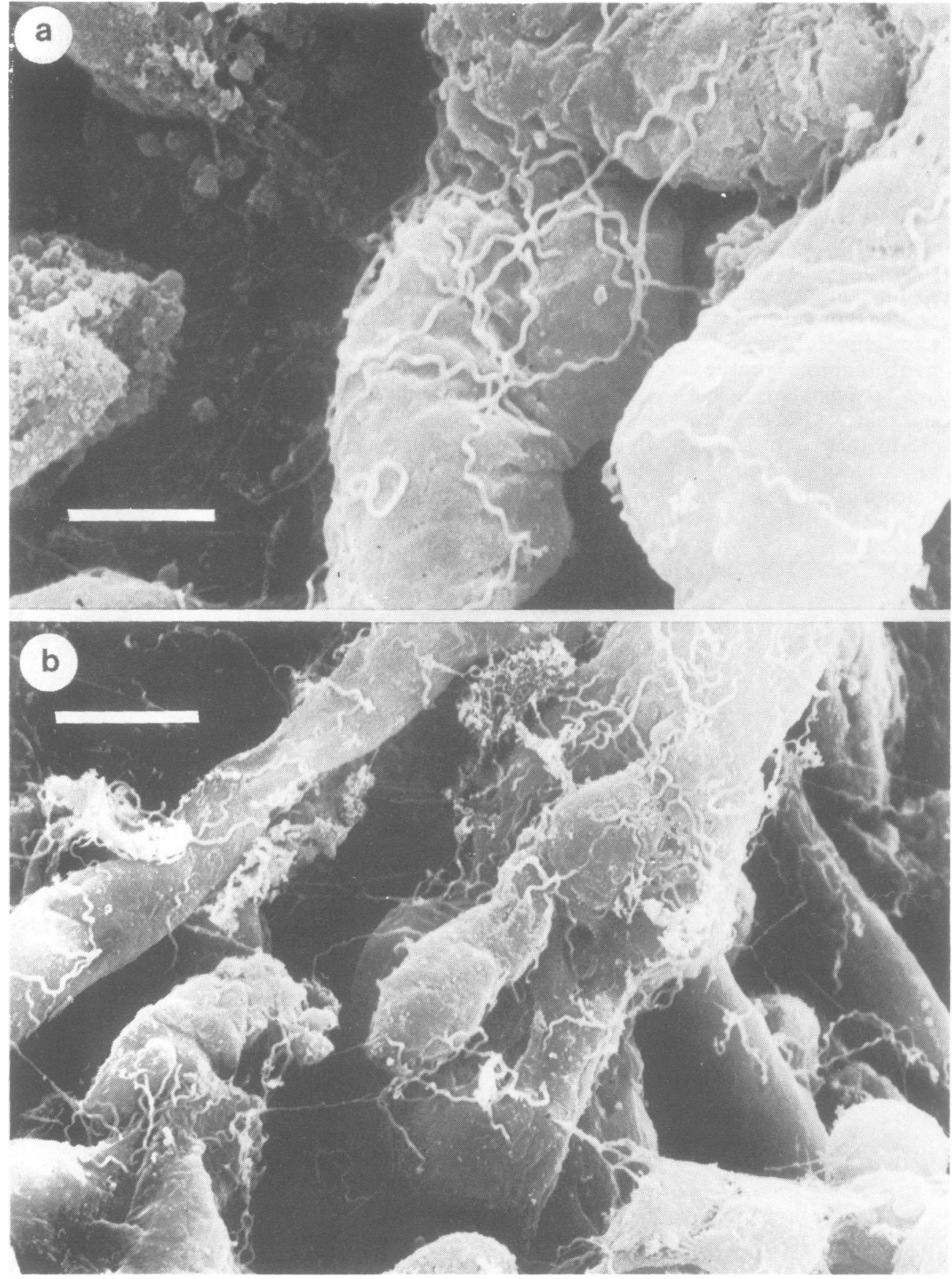

FIG 2 Scanning electron micrographs of treponemes incubated with capillaries for: (a) 30 minutes, bar represents $10 \mu \mathrm{m}$; (b) 24 hours, bar represents $5 \mu \mathrm{m}$. 
coverslips, thus facilitating fixation, dehydration, and critical-point drying. Attached treponemes, however, were obscured by this network of fibrillar strands. When the treponemal preparations were centrifuged at high speed, and the organisms resuspended in fresh medium, this fibrin-like reaction did not occur. Apparently some soluble component of the slow-speed preparation reacted with the capillaries to produce the strand formation; this reaction does not occur using tissue culture cells.

In the absence of this strand formation fixation and processing resulted in an appreciable loss of capillaries. To attain better adherence of capillaries glass coverslips were pre-coated with either poly-Llysine or collagen. Slightly better adherence of capillaries occurred but losses were still high. As an alternative to coverslip adherence capillaries were placed on Gelman filters (pore size, $0.45 \mu \mathrm{m}$ ) and washed and fixed within the filter units. Capillaries towards the centre of the filter were flattened, possibly owing to excessive pressure; capillaries at the periphery of the filter, however, appeared normal.

With increasing periods of incubation increasing numbers of $T$ pallidum attached. A preparation of $6 \times 10^{7}$ organisms $/ \mathrm{ml}$ was added to capillaries. Fig $2 \mathrm{a}$ shows treponemal attachment after 30 minutes. The organisms appeared to be attached along their entire length rather than just at their tips. This is artifactual, however, as shown by phase contrast and darkfield microscopy of actively motile attached organisms. Fig $2 \mathrm{~b}$ shows treponemal attachment after 24 hours' incubation. The lack of organisms away from the capillaries indicates the effectiveness of the washing procedures.

A small percentage of the microvessels showed a banded appearance about their circumference. These were probably arterioles surrounded by smooth muscle. Fig 3a shows $T$ pallidum attached to a portion of one of these vessels. In addition, on rare occasions what appeared to be a half-treponeme was observed at the surface of capillaries. As shown in fig $3 \mathrm{~b}$ these organisms were about $5 \mu \mathrm{m}$ instead of 10-20 $\mu \mathrm{m}$ in length, and contained 3-5 coils instead of 10-14 coils. Since a half-treponeme has never been previously reported, it is assumed that this represented an organism penetrating into the capillary vessel.

After incubation for $\mathbf{4 8}$ hours there appeared to be some capillary destruction. In fig $4 a$ the remnants of capillary structure suggested pronounced endothelial cell destruction. Control preparations incubated for 48 hours with heat-inactivated $T$ pallidum (fig $4 \mathrm{~b}$ ), the high-speed supernatant from the infected testicular extract, or culture medium showed normal morphology. This apparent capillary destruction mediated by viable attached $T$ pallidum was also observed by darkfield and phase contrast microscopy. As shown in fig 5a nuclear detail of endothelial cells was lost, capillaries were emaciated and deformed, and fewer red blood cells were entrapped. In contrast, control preparations showed normal morphology (fig 5b).

During these extended incubation studies the attachment of treponemes enhanced their survival. In the next series of experiments $5 \times 10^{7}$ organisms $/ \mathrm{ml}$ were incubated with capillaries in the presence of different concentrations of heated normal rabbit serum (NRS). Four preparations were used: $100 \%$ NRS, $50 \%$ NRS-50\% culture medium, $10 \%$ NRS-90\% culture medium, or $100 \%$ culture medium. Three separate experiments yielded similar results. Fig 6 shows the time required to reach $50 \%$ motility $\left(\mathrm{T}_{50}\right)$. In each of the four preparations the attached organisms survived longer. In addition, much better survival occurred and more organisms were attached in $100 \%$ NRS and $50 \%$ NRS.

The preincubation of $T$ pallidum with immune rabbit serum (IRS) followed by incubation with tissue culture cells resulted in reduced treponemal attachment. ${ }^{56}$ Attempts were made to extend these findings to the capillary preparations. Organisms were preincubated in normal rabbit serum (NRS) or IRS overnight. In each of five separate experiments after preincubation motilities were similar in both NRS and IRS preparations (table). After preincubation the treponemes were added to capillaries. After 3.5 to 4.5 hours the numbers of attached organisms were determined. IRS contains a

TABLE Blockage of treponemal attachment to capillaries after preincubation in immune rabbit sera

\begin{tabular}{|c|c|c|c|c|c|}
\hline \multirow[b]{2}{*}{ Experiment } & \multicolumn{2}{|c|}{$\begin{array}{l}\% \text { Motile after preincubation with } \\
\text { sera for } 18 \text { to } 22 \mathrm{~h}\end{array}$} & \multicolumn{2}{|c|}{$\begin{array}{l}\text { Treponemes attached per } 10 \text { capillaries } \\
\text { after incubation for } 3.5 \text { to } 4.5 \mathrm{~h}\end{array}$} & \multirow[b]{2}{*}{ \% Blocked } \\
\hline & $N R S$ & IRS & $N R S$ & IRS & \\
\hline $\begin{array}{l}1 \\
2 \\
3 \\
4 \\
5\end{array}$ & $\begin{array}{l}78 \\
96 \\
92 \\
80 \\
96\end{array}$ & $\begin{array}{l}88 \\
88 \\
96 \\
80 \\
96\end{array}$ & $\begin{array}{r}65 \\
115 \\
110 \\
75 \\
65\end{array}$ & $\begin{array}{r}25 \\
45 \\
35 \\
5 \\
15\end{array}$ & $\begin{array}{l}62 \\
61 \\
68 \\
93 \\
77\end{array}$ \\
\hline
\end{tabular}

NRS = pooled normal rabbit sera; $I R S=$ pooled immune rabbit sera 

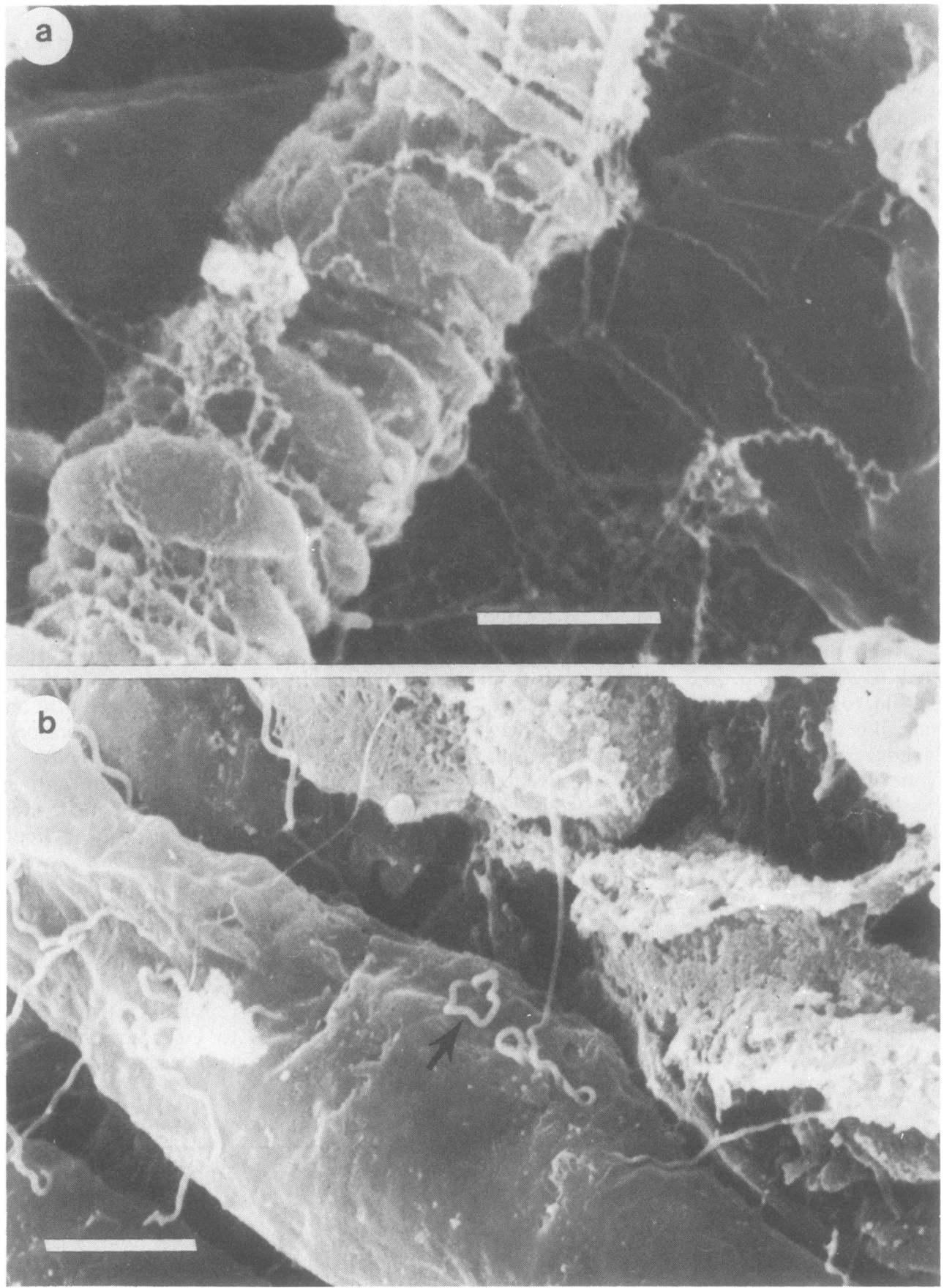

FIG 3 Scanning electron micrographs showing: (a) treponemes attached to banded microvessels which are probably arterioles surrounded by smooth muscle, bar represents $15 \mu \mathrm{m} ;$ (b) an apparent halftreponeme (arrow) which is much shorter than other treponemes, bar represents $8 \mu \mathrm{m}$. 

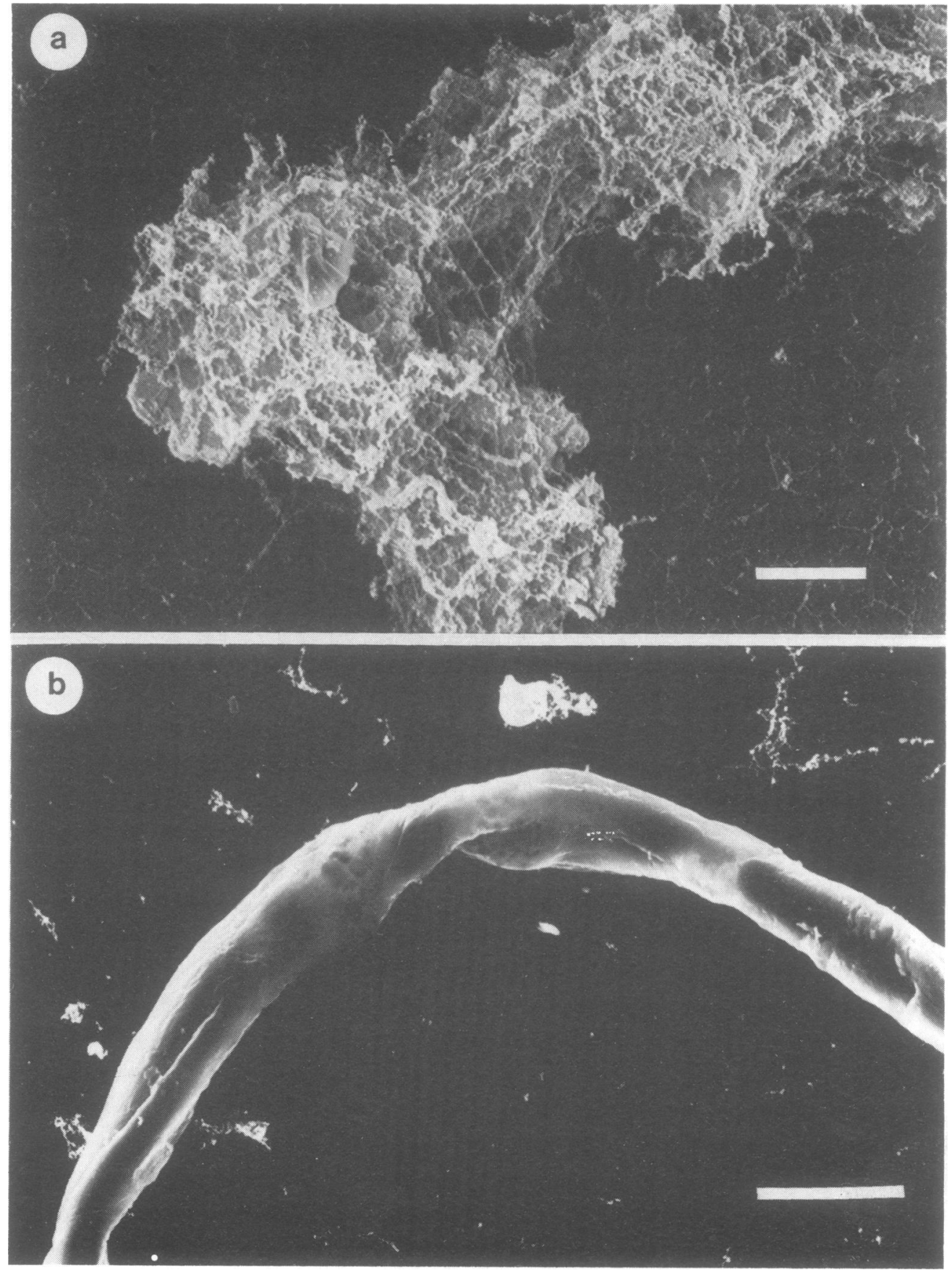

FIG 4 Scanning electron micrographs after 48 h of incubation with: (a) viable treponemes showing apparent capillary damage, bar represents $15 \mu \mathrm{m}$; (b) control of heated treponemes showing normal capillary morphology, bar represents $30 \mu \mathrm{m}$. 

E E Quist, L A Repesh, $R$ Zeleznikar, and T J Fitzgerald $\stackrel{\frac{\Phi}{c}}{\stackrel{\Phi}{\Phi}}$

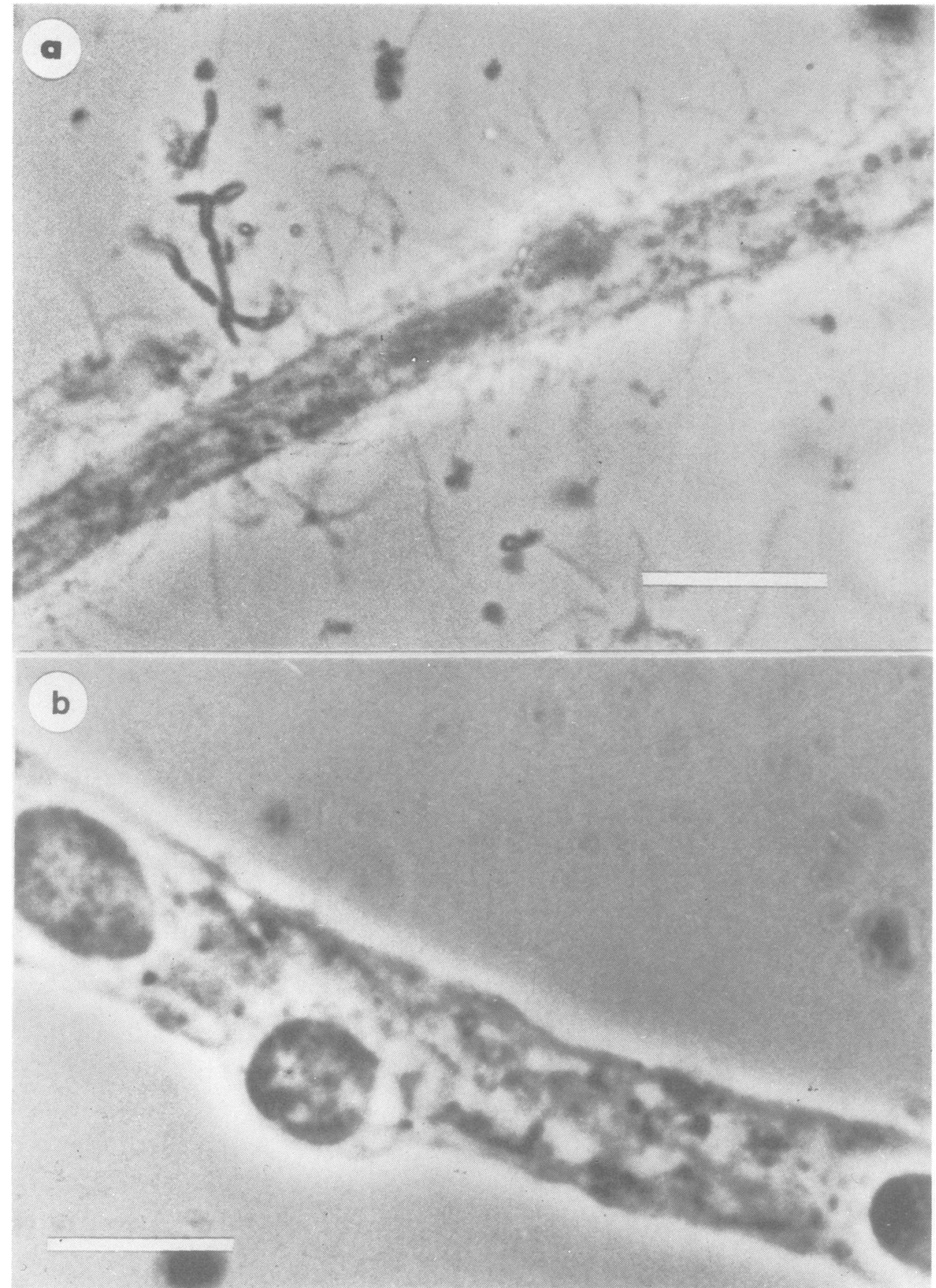

FIG 5 Phase contrast micrographs after 48 h of incubation with: (a) viable treponemes, bar represents $20 \mu \mathrm{m}$; (b) heated treponemes, bar represents $10 \mu \mathrm{m}$. 


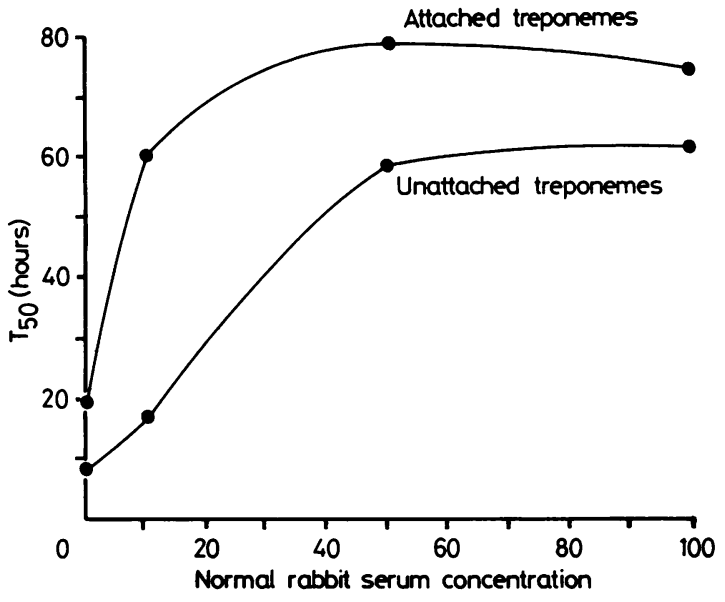

FIG 6 Increased survival of attached versus unattached organisms. $T_{50}$ represents the time $(h)$ required for the treponemal preparations to reach $50 \%$ motility.

factor that partially blocks treponemal attachment to the capillaries. In five experiments the percentage blocked ranged from $61 \%$ to $93 \%$. This confirms our previous findings using tissue culture cells, ${ }^{5}$ in which the percentage blocked ranged from $73 \%$ to $100 \%$.

\section{Discussion}

Procedures have been established for isolating intact capillaries from dogs and rats. ${ }^{8-10}$ We have adapted these procedures to study the interaction of $T$ pallidum with rabbit capillaries. To our knowledge this is the first report of the in-vitro interaction of micro-organisms with capillaries. Similar procedures might be useful for studying other organisms that infect vascular tissues such as rickettsia, trypanosomes, and certain viruses.

Cultured mammalian cells have provided a useful tool to characterise aspects of pathogenesis and host immune responses in syphilis. ${ }^{2}$ These cells, however, do not possess the identical properties of the same cells in vivo. Intact capillary preparations approximate in-vivo conditions more closely. The interaction of $T$ pallidum with capillaries was quite similar to that with cultured cells. The mechanism of attachment of $T$ pallidum and $T$ pertenue, 45712 the extension of survival of attached organisms, ${ }^{4}$ and the lack of attachment by heated $T$ pallidum and nonpathogenic treponemes ${ }^{4} 5$ were initially reported using tissue culture cells. Since syphilis is primarily a vascular disease capillary-treponemal interaction should provide pertinent information about hostparasite relationships.

The findings of this study may explain certain aspects of syphilitic disease. After entering the host $T$ pallidum immediately disseminates to other tissues. ${ }^{1}$ Because of its rapid nature dissemination must occur through the bloodstream either by direct penetration of blood vessels or by penetration of lymphatic channels which subsequently empty into the blood. Once in the bloodstream the process reverses and treponemes penetrate through endothelial cells to gain perivascular access to other tissues. Lauderdale and Goldman ${ }^{13}$ and Ovcinnikov and Delektorskij ${ }^{14}$ published transmission electron micrographs of infected tissue in which treponemes were intimately associated with the lumen of capillaries. Ovcinnikov and Delektorskij ${ }^{14}$ suggested that $T$ pallidum penetrated between the junctions of endothelial cells. Using intact capillaries we have occasionally observed what appears to be a half-treponeme. The mechanism of penetration may be partially attributed to the treponemal hyaluronidase enzyme. ${ }^{15} 16$ Capillary endothelial cells are joined together by ground substance comprised of glycosaminoglycans (primarily hyaluronic acid), glycoproteins, and proteins. ${ }^{17-19} T$ pallidum may degrade the hyaluronic acid enzymatically thereby splitting apart the endothelial cell junctions. This would explain both direct entry into the bloodstream and subsequent exit from the bloodstream into surrounding tissues.

The treponemal hyaluronidase enzyme may also play a role in capillary destruction. Ground substance provides structural support for capillaries. ${ }^{17-19}$ With extensive perivascular multiplication of organisms degradation of the hyaluronic acid would damage capillary structural support. In turn collapsed vessels would result in the inhibited blood supply, necrosis, and ulceration that are characteristic of syphilitic histopathology. In support of the potential pathological role of hyaluronidase $T$ pertenue attached to capillaries and possesses this enzyme ${ }^{16}$; in contrast, the nonpathogenic treponemes did not attach and lack this enzyme. ${ }^{16}$

Lastly, immune serum blocked treponemal attachment to isolated capillaries. Similar findings were reported using cultured cells. ${ }^{5}$ Blockage of attachment by humoral factors may partially explain the immunity following infection. When immune rabbits are challenged with $T$ pallidum viable organisms remain localised at the injection site and do not disseminate to draining lymph nodes or to other tissues. ${ }^{20-23}$ This lack of dissemination may reflect the inability of treponemes to attach to the outer surface of capillaries and to penetrate through endothelial cells to enter the bloodstream. Alternatively, if the organisms enter the bloodstream through the lymphatics, they may not be able to attach to the inner surface of capillaries thereby preventing access to other tissues. 
We express our appreciation to Eileen Gannon for expert technical assistance in performing this research. Support was provided by Public Health Service, National Institute of Allergy and Infectious Diseases grant AI-16 585, Minnesota Medical Foundation grants DMRF 53-80 and DMRG 52-80, and the University of Minnesota Graduate School grants 464-0325-4909 and 461-0325 4909.

\section{References}

1. Turner TB, Hollander DH. Biology of the treponematoses. WHO Monograph Series No 35. Geneva: World Health Organisation, 1957.

2. Fitzgerald TJ. Pathogenesis and immunology of Treponema pallidum. Ann Rev Microbiol 1981;35:29-54.

3. Wright MI. Exploratory studies in tissue culture of $T$ pallidum. Proceedings of the XII International Congress of Dermatology 1962;2:884-7.

4. Fitzgerald TJ, Miller JN, Sykes JA. Treponema pallidum (Nichols strain) in tissue cultures: cellular attachment, entry, and survival. Infect Immun 1975;11:1133-40.

5. Fitzgerald TJ, Johnson RC, Miller JN, Sykes JA. Characterization of the attachment of Treponema pallidum (Nichols strain) to cultured mammalian cells and the potential relationship of attachment to pathogenicity. Infect Immun 1977; 18:467-78.

6. Hayes NS, Muse KE, Collier AM, Baseman JB. Parasitism by virulent Treponema pallidum of host cell surfaces. Infect Immun 1977;17:174-86.

7. Fieldsteel AH, Stout JG, Becker FA. Comparative behaviour of virulent strains of Treponema pallidum and Treponema pertenue in gradient cultures of various mammalian cells. Infect Immun 1979;24:337-45.
8. Brendel K, Meezan E, Carlson EL. Isolated brain microvessels: a purified metabolically active preparation from bovine cerebral cortex. Science 1974; 185:953-5.

9. Drewes LD, Lidinsky WA. Studies of cerebral capillary endothelial membrane. Adv Exp Med Biol 1980;131:17-27.

10. Joo F, Karnushina I. A procedure for the isolation of capillaries from rat brain. Cytobios 1973;8:41-8.

11. Sykes JA, Moore EB. A simple tissue culture chamber. Tex Rep Biol Med 1960;18:288-97.

12. Fitzgerald TJ, Cleveland P, Johnson RC, Miller JN, Sykes JA Scanning electron microscopy of Treponema pallidum (Nichols strain) attached to cultured mammalian cells. J Bacteriol 1977; 130:1333-44.

13. Lauderdale V, Goldman JN. Serial ultrathin sectioning demonstrating the intracellularity of $T$ pallidum. $B r J$ Vener Dis 1972;48:87-99.

14. Ovcinnikov NJ, Delektorskij VV. Electron microscopy of phagocytosis in syphilis and yaws. $B r J$ Vener Dis 1972;48:227-48.

15. Fitzgerald TJ, Johnson RC. Mucopolysaccharidase of Treponema pallidum. Infect Immun 1979;24:261-8.

16. Fitzgerald TJ, Gannon EM. Further evidence for hyaluronidase activity associated with Treponema pallidum. Infect Immun, in press.

17. Gersch I, Catchpole HR. The organization of ground substance and basement membrane and its significance in tissue injury, disease, and growth. Am J Anat 1949;85:457-521.

18. Luft JH. Fine structure of capillary and endocapillary layer as revealed by ruthenium red. Fed Proc 1966;24:1773-83.

19. Luft JH. Ruthenium red and violet. II Fine structural localization in animal tissues. Anat $\operatorname{Rec} 1971$; 171:369-416.

20. Chesney AM, Kemp JE. Studies in experimental syphilis. VI On variations in the response of treated rabbits to reinoculation; and on cryptogenetic reinfection with syphilis. $J$ Exp Med 1926;44:589-606.

21. Cumberland MC, Turner TB. The rate of multiplication of $T$ pallidum in normal and immune rabbits. $A m J$ Syph 1949;33:201-12.

22. Reynolds FW. The fate of Treponema pallidum inoculated subcutaneously into immune rabbits. Bulletin of the Johns Hopkins Hospital 1941;69:53-60.

23. Waring GW, Fleming WL. The effect of partial immunity on the dissemination of infection in experimental syphilis. Am Syph 1952;36:268-375. 